PYTHAGORAS: Jurnal Pendidikan Matematika

Volume 10 - Nomor 2, Desember 2015, (211-221)

Available online at: http://journal.uny.ac.id/index.php/pythagoras

\title{
Pengembangan Perangkat Pembelajaran Lingkaran SMP Kelas VIII dengan Suplemen Materi History of Mathematics (HOM)
}

\author{
Tri Hidayati ${ }^{1)}$, Djamilah Bondan Widjajanti ${ }^{2)}$ \\ ${ }^{1}$ Pendidikan Matematika, Universitas Pamulang. Jalan Surya Kencana No. 1 Pamulang-Tangerang \\ Selatan, Banten, Indonesia. Email: trihidayati88@gmail.com \\ ${ }^{2}$ Pendidikan Matematika, Universitas Negeri Yogyakarta, Jalan Colombo No. 1, Karangmalang, \\ Yogyakarta 55281, Indonesia. Email: dj_bondan@yahoo.com
}

\begin{abstract}
Abstrak
Tujuan penelitian ini adalah menghasilkan perangkat pembelajaran lingkaran SMP Kelas VIII dengan suplemen materi History of Mathematics (HoM) yang terdiri atas RPP dan Modul yang memenuhi kriteria valid, praktis, dan efektif. Model pengembangan ynag digunakan adalah model ADDIE (Analysis, Design, Development, Implementation, dan Evaluation). Analisis data kevalidan dan kepraktisan dilakukan dengan cara mengkonversi skor empiris yang diperoleh menjadi data kualitatif skala lima. Analisis keefektifan dilakukan dengan cara menentukan persentase banyak siswa yang mencapai kategori minimal tinggi untuk angket dan menentukan persentase ketuntasan siswa pada tes prestasi belajar. Berdasarkan hasil validasi, RPP dan Modul yang dikembangkan memenuhi kriteria valid dengan kategori sangat baik. RPP dan Modul yang dikembangkan praktis dan efektif. Kepraktisan perangkat pembelajaran yang dikembangkan mencapai kategori sangat baik berdasarkan hasil observasi keterlaksanaan pembelajaran dan penilaian guru, modul mencapai kategori baik berdasarkan respon siswa. Perangkat pembelajaran juga efektif ditinjau dari motivasi, rasa ingin tahu, dan prestasi belajar siswa.
\end{abstract}

Kata Kunci: pengembangan, perangkat pembelajaran, History of Mathematics

\section{Developing Circle Instructional Kits of $8^{\text {th }}$ Grade Junior High School with the Supplement of History of Mathematics (HOM) Material}

\begin{abstract}
This research aims to produce the circle instructional kits for $8^{\text {th }}$ grade Junior High School with the supplement of history of mathematics (HoM), consists of lesson plans and module. The developing model was ADDIE's model (Analysis, Design, Development, Implementation, and Evaluation). The validity and practicality of the data were analyzed by converting the empiric scores obtained into five scale qualitative data. The effectivity was analyzed by determining the percentage of students who reached minimally high category of the questionnaires and determining the percentage of student's completeness in the achievement test. Based on the validation result of lesson plans and module which have been developed, they include in valid criteria with very good category. Lesson plans and module which have been developed are practical and effective. The Practicability of instructional kits that are developed reach very good category that based on observation result of lesson implementation and teacher's evaluation, the module reaches good categoty that based on students' response. Instructional kits also effective based on students' motivation, curiosity, and achievement.
\end{abstract}

Keywords: development, instructional kit, History of Mathematics

How to Cite Item: Hidayati, T., \& Widjajanti, D. (2015). Pengembangan perangkat pembelajaran lingkaran SMP Kelas VIII dengan suplemen materi history of mathematics (HOM). PYTHAGORAS: Jurnal Pendidikan Matematika, 10(2), 211-221. doi:http://dx.doi.org/10.21831/pg.v10i2.9168 


\section{PENDAHULUAN}

Peran matematika untuk kemajuan sangatlah penting, sehingga siswa diharapkan bisa menguasai materi dengan baik. Melihat pentingnya matematika dan peranannya dalam menghadapi kemajuan ilmu pengetahuan dan teknologi serta persaingan global maka peningkatan mutu pendidikan matematika di semua jenis dan jenjang pendidikan harus selalu diupayakan (Wahyuni \& Abadi, 2014, p.1). Selain itu, pembelajaran matematika yang dilaksanakan hendaknya sesuai dengan standar proses yang menuntut suatu pembelajaran yang inspiratif dan efektif. Sayangnya dalam hasil survei lembaga PISA dan TIMSS, memaparkan rendahnya kemampuan siswa Indonesia dalam penguasaan matematika.

Salah satu lembaga internasional yang melakukan penilaian kemampuan siswa di berbagai negara, PISA atau Programme for International Student Assessment, melaporkan pada tahun 2012 Indonesia kembali menempati posisi rendah. Keterampilan dan kemampuan dalam PISA yang dinilai meliputi matematika (mathematics literacy), membaca (reading literacy), dan sains (science literacy). Pada PISA 2012 ada tambahan penilaian yang dilakukan yaitu literasi pemecahan masalah (problem solving literacy) dan literasi finansial (financial literacy). Dari berbagai keterampilan tersebut, siswa Indonesia menempati peringkat 64 dari 65 negara yang terlibat dengan skor rata-rata 375 dimana skor rata-rata PISA adalah 494 (OECD, 2014, p.19). Dari peringkat tersebut menunjukkan bahwa kemampuan matematika siswa Indonesia masih rendah.

Selain data di atas, menurut hasil TIMSS 2011, peringkat anak-anak Indonesia berada pada posisi 38 dari 42 negara untuk prestasi matematika (Provasnik, 2012, p.150). Rata-rata skor prestasi matematika adalah 386, skor ini masih berada di bawah skor rata-rata internasional. Capaian rata-rata peserta Indonesia pada TIMSS 2011 mengalami penurunan dari capaian rata-rata pada TIMS 2007 yaitu 397, dimana kerangka kerja TIMSS 2011 tidak berbeda dengan kerangka kerja TIMSS 2007. Dalam survei TIMSS, Indonesia menduduki peringkat 36 dari 48. Rata-rata kemampuan matematika siswa Indonesia adalah 397, sedangkan rata-rata skor TIMSS adalah 500 (Gonzales, 2009, p.7). Data ini menunjukkan bahwa kemampuan matematika siswa Indonesia masih jauh dari apa yang diharapkan.
Sedangkan berdasarkan laporan hasil UN SMP/MTs oleh BSNP tahun 2013/2014 rata-rata nasional untuk mata pelajaran matematika adalah 5,78, capaian ini menurun dibandingkan dengan rata-rata nasional tahun sebelumnya yaitu 7,54. Namun rata-rata nilai UN matematika tahun 2013/2014 untuk provinsi DIY adalah 6,12 . Artinya secara nasional prestasi belajar matematika siswa belum seragam ada yang tinggi, sedang dan rendah. Secara nasional provinsi DIY berada di atas rata-rata, namun untuk kota dan kabupaten yang berada di DIY juga tidak seragam. Kota Yogyakarta menduduki peringkat pertama untuk capaian rata-rata nilai UN matematika tahun 2013 yaitu sebesar 6,93. Capaian ini berada di atas rata-rata baik secara nasional maupun provinsi. Akan tetapi capaian ini tidak berlaku untuk seluruh SMP/MTs di Kota Yogyakarta. Salah satu sekolah yang rata-rata nilai UN matematikanya di bawah rata-rata adalah SMP N 15 Yogyakarta dengan rata-rata nilainya 6,89 . Hal tersebut menunjukkan bahwa prestasi belajar matematika siswa di SMP N 15 Yogyakarta masih tergolong rendah.

Prestasi belajar matematika siswa juga dapat dilihat berdasarkan nilai Ulangan Tengah Semester (UTS). Berdasarkan nilai UTS kelas VIII di SMP N 15 Yogyakarta, rata-rata nilai matematika yaitu 73 Nilai UTS matematika tertinggi adalah 96 dan terendah adalah 36. Data tersebut menunjukkan bahwa prestasi belajar matematika siswa kelas VIII SMP N 15 Yogyakarta masih kurang maksimal. Berdasarkan data tersebut, perlu adanya suatu upaya perbaikan dalam kegiatan pembelajaran agar pencapaian prestasi belajar matematika siswa lebih optimal. Prestasi belajar adalah nilai yang menunjukkan kemampuan penguasaan pengetahuan dan pemahaman siswa dari proses belajar yang diatur dalam kurikulum dan rentang waktu tertentu (Azwar, 2000, p.13; Reynold \& Kamphaus, 2003, p.29; Gronlund, 1977, p.1; Arends \& Kilcher, 2010, p.59; Hawkins, Florian \& Rose, 2007, p.28, p.22) .

Selain memperhatikan kompetensi pengetahuan, hendaknya guru juga memperhatikan kompetensi sikap siswa. Hal tersebut sesuai dengan Permendikbud No. 66 Tahun 2013 tentang Standar Penilaian Pendidikan bahwa penilaian hasil belajar peserta didik mencakup kompetensi sikap, pengetahuan, dan ketrampilan. Penilaian kompetensi sikap dapat berupa skala penilaian terhadap motivasi belajar, rasa ingin tahu siswa, sikap siswa terhadap matematika, keaktifan siswa, dan kemandirian siswa. 
permasalahan tersebut, siswa Indonesia juga memiliki motivasi yang rendah untuk belajar matematika. Selama ini, penilaian yang dilakukan oleh guru masih lebih banyak mennekankan pada aspek kognitif atau kompetensi pengetahuan siswa dibandingkan kompetensi sikap. Padahal ada permasalahan juga terkait kompetensi sikap, salah satunya motivasi belajar. Indikasi ini terlihat ketika peneliti melakukan observasi prapenelitian di sekolah.

Motivasi belajar adalah keinginan atau daya penggerak psikis yang mengakibatkan seseorang untuk belajar yang ditandai dengan intensitas atau energi, arah dan ketekunan kepada kegiatan belajar itu demi mencapai suatu tujuan pembelajaran (Winkel, 2005, p.169; Cohen \& Swedlik, 2005, p.550; Santrock, 2007, p.510; Hook \& Vass, 2011, p. 65; Dai, 2004, p.11; Djamarah, 2002, p. 114; Evan, 1999, p.7). Sebagaimana yang ditegaskan Sardjoko (2011, p.93) bahwa siswa dengan motivasi belajar tinggi, prestasi belajar akan lebih baik dari pada siswa dengan motivasi belajar yang rendah. Oleh karena iu, pembelajaran berkaitan erat dengan motivasi belajar.

Dari hasil wawancara dengan guru pengampu mata pelajaran matematika, menjelaskan bahwa sebagian siswa masih menganggap bahwa matematika adalah momok bagi mereka. Sehingga mereka semakin enggan untuk memperdalam pemahaman mereka atas materi matematika yang diajarkan. Selain itu, peneliti juga meminta siswa untuk melakukan pengisian angket awal motivasi belajar siswa di SMP N 15 Yogyakarta. Berdasarkan angket motivasi belajar siswa yang terdiri atas 24 butir pernyataan dengan menggunakan kriteria dari Widoyoko diperoleh kesimpulan tingkat motivasi belajar siswa berada pada kategori sedang. Kurangnya motivasi dalam mempelajari materi bisa berdampak buruk pada kemampuan siswa. Oleh karena itu, motivasi sangat berperan penting dalam pembelajaran matematika.

Masalah lain yang muncul dalam pembelajaran matematika terkait kompetensi sikap diantaranya lemahnya rasa ingin tahu siswa. Rasa ingin tahu adalah suatu sistem perasaan yang disebabkan oleh rangsangan indrawi maupun pikiran yang terbentuk dari indikator berupa perasaan yang mendorong untuk memecahkan masalah yang berasal dari pikirannya dan perasaan yang mendorong untuk melakukan penjelajahan/inspeksi demi pengetahuan baru (Santoso, 2005, p.233; Loewenstein, 1994, p.75; Zuss, 2012, p.73; Jones \& Flint, 2013, p.126, p.
134; Engel, 2015, p. 38; Sulistyowati, 2012, p. 74).

Berdasarkan pengisian angket awal rasa ingin tahu siswa terhadap matematika yang terdiri atas 24 butir pernyataan dengan menggunakan kriteria dari Widoyoko diperoleh kesimpulan tingkat rasa ingin tahu siswa terhadap matematika berada pada kategori sedang. Seperti yang telah dijelaskan bahwa kurikulum 2013 menuntut suatu bentuk pembelajaran saintifik dimana rasa ingin tahu merupakan faktor kunci dalam keberhasilan pembelajaran tersebut. Dalam pembelajaran yang berlandaskan kurikulum 2013, siswa dituntut untuk menemukan pengetahuannya sendiri. Namun dengan kurangnya rasa ingin tahu siswa, dorongan untuk hal tersebut masih rendah.

Dari pengamatan peneliti di sekolah, pelajaran matematika diajarkan menggunakan buku ajar yang menekankan pada rumus dan pengerjaan soal. Ketika pembelajaran berlangsung, proses pembelajaran bertumpu pada buku paket yang cenderung didaktis. Dengan proses pembelajaran tersebut, matematika akan dianggap sebagai pelajaran yang tidak aplikatif dan jauh dari realitas kehidupan. Matematika akan dipandang sebagai pelajaran yang abstrak dan rumusrumusnya diterima secara taken for granted. Hal yang tidak jauh berbeda juga terjadi di sekolah di Singapura. Saat ini sejarah matematika tidak memiliki tempat dalam pendidikan matematika di sekolah-sekolah dan juga politeknik di Singapura, baik secara resmi maupun official (Ho, 2008, p.8).

History of Mathematics (HoM) diartikan sebagai suatu proses pertumbuhan dan perkembangan pengetahuan matematika serta investigasi tentang proses perkembangan gagasan dan konsep matematika. History of Mathematics (HoM) dalam pembelajaran matematika adalah aplikasi penggunaan sejarah matematika dalam pembelajaran materi matematika di kelas. (Lim \& Chapman, 2010, p.114, Durbin, 2012; Swetz, 1994, p.1). Menurut Goktepe (2013, p.125) peran sejarah matematika dalam pendidikan matematika bukanlah sesuatu yang baru. Sejarah matematika diimplementasikan dalam pembelajaran matematika sejak tahun 1960an dan 1970an sebagaimana yang dilakukan oleh oleh Schubring, Furinghetti \& Siu, 2012; Fauvel \& Maanen, 1997. Walaupun bukan sesuatu yang baru, namun penggunaan sejarah matematika dalam pembelajaran di Indonesia masih merupakan hal yang baru. 


\section{Pythagoras, 10 (2), Desember 2015 - 214}

Tri Hidayati, Djamilah Bondan Widjajanti

Meskipun ada beberapa buku teks menyediakan potongan sejarah matematika, namun hal tersebut tidak ditempatkan secara benar, yakni hanya diposisikan sebagai materi ekstra yang bisa saja dibuang oleh guru dalam proses pembelajaran (Ho, 2008, p.8). Dengan buku ajar yang tidak memberikan konteks historis bagi siswa secara memadai, menjadikan siswa bosan dan pembelajaran yang bermakna sulit tercapai. Salah satu faktor yang menyebabkan ketertinggalan siswa dalam matematika adalah terbatasnya modul dan buku matematika yang bisa menyajikan materi matematika dengan paduan historis-kontekstualnya.

Buku ajar yang ada di SMP N 15 Yogyakarta dalam menyajikan materi lebih menekankan pada rumus yang harus dihafal siswa dan berbagai soal-soal yang harus dikerjakan, serta belum mengintegrasikan HoM (History of Mathematics) dalam materi yang diajarkan. Sajian materi matematika dalam proses pembelajarannya lebih cenderung menunjukan sisi kalkulatif dari matematika. Matematika dianggap sebagai kumpulan rumus dan kegiatan menyelesaikan soal, dan matematika tidak dianggap sebagai sebuah produk sejarah dan peradaban. Inilah sisi matematika yang terlewatkan dalam pembelajaran. Hilangnya sisi historis dan kontekstual yang memberikan landasan bagaimana suatu konsep matematika terbentuk menyebabkan matematika oleh siswa dianggap sebagai ilmu yang jauh dari realitas kehidupan manusia. Padahal, matematika adalah sesuatu yang diciptakan oleh manusia, dalam sejarah dan kondisi tertentu.

Lim \& Chapman (2010, p.124), menyatakan bahwa, dengan penggunaan HoM tersebut, baik domain afektif maupun kognitif siswa dapat ditingkatkan sekaligus. Dengan pembelajaran matematika yang memuat HoM, berbagai permasalahan baik afektif maupun kognitif seperti rendahnya prestasi, dan rendahnya rasa ingin tahu bisa teratasi. Untuk mendapatkan proses pendidikan yang bermakna dan menumbuhkan kecintaan siswa pada matematika, pembelajaran matematika perlu menyajikan materi beserta konteks historisnya. Sebagaimana yang dijelaskan oleh Goktepe \& Ozdemir (2013, p.126) bahwa proses pembelajaran yang dibentuk dengan HoM dapat meningkatkan motivasi dan sikap positif siswa terhadap matematika. Sehingga, dengan implementasi sejarah matematika, diharapkan motivasi siswa dalam belajar matematika dapat meningkat. Maka, untuk memberi pengertian yang mendalam tentang materi matematika dan menumbuhkan motivasi belajar, perlu adanya penyusunan materi dimana sejarah matematika menjadi bagian dari materi yang diajarkan. Dengan adanya sejarah bagaimana suatu konsep matematika tercipta, siswa akan memiliki pandangan yang lebih holistik pada materi tersebut, dan mereka akan lebih tertarik untuk mempelajarinya.

Goktepe \& Ozdemir (2013, p.126) juga enerangkan manfaat penggunaan HoM dalam belajar matematika. Mereka menjelaskan bahwa dengan melihat hambatan-hambatan yang dialami dalam pengembangan matematika pada masa lalu membuat mereka bisa melihat kesulitan yang ditemui pada masa kini, penyelesaian masalah yang ada pada sejarah membantu perkembangan siswa dalam berfikir matematis, sejarah membawa sisi-sisi kemanusiaan dari pengetahuan matematika. Dengan manfaat yang bisa diperoleh dari HoM tersebut, memungkinkan guru untuk membuat pembelajaran yang interaktif dan memacu motivasi siswa yang sesuai dengan standar proses pendidikan yang tercantum dalam Permendikbud No 65 Tahun 2013.

Nayazik (2012, p.1) dalam tulisannya yang berjudul "Pembelajaran matematika dengan menginterasikan HoM untuk meningkatkan motivasi siswa", melakukan kajian pustaka untuk menganalisis bagaimana sejarah matematika dapat berkontribusi dalam meningkatkan motivasi serta bagaimana penggunaan HoM tersebut bisa dilakukan. Dalam tulisannya Nayazik $(2012$, p.7) menegaskan bahwa salah satu pembelajaran matematika yang dapat meningkatkan motivasi belajar adalah karena dengan menginterasikan konteks sejarah. Dengan hal ini materi yang disajikan akan lebih bermakna bagi para siswa.

Menurut Lim \& Chapman (2010, p.115) penggunaan HoM dalam pembelajaran matematika di kelas bisa diimplementasikan sebagai suplemen materi melalui: 1. Penggunaan anekdot dan biografi ahli matematika dalam sejarah, 2. Pembahasan perkembangan sejarah matematika yang motivatif dalam konten materi, 3 . Penggunaan materi asli dari sumber sejarah matematika, 4. Pembelajaran topik yang sesuai dengan perkembangan kronologis pada sejarah matematika. Keempat teknik tersebut bisa diaplikasikan menjadi suatu bahan ajar yang bermakna, sehingga bisa membantu siswa untuk menemukan (inquiry) bagaimana suatu gagasan matematika dibentuk. Dengan berbagai hal tersebut, suplemen HoM bisa memberikan dampak positif pada pembelajaran matematika di kelas. 
Dari penjabaran tersebut terlihat bahwa perlu adanya suatu proses pembelajaran matematika yang bisa memotivasi dan bisa menyajikan materi beserta konteks historisnya, sehingga menuntun siswa untuk memahami bagaimana suatu konsep matematika terbentuk. Oleh karena itu, peneliti tertarik untuk mengembangkan perangkat pembelajaran dengan suplemen materi History of Mathematics (HoM) untuk meningkatkan motivasi, rasa ingin tahu dan prestasi belajar siswa dalam mata pelajaran matematika pokok bahasan lingkaran. Oleh karena itu, penelitian ini bertujuan untuk menghasilkan perangkat pembelajaran lingkaran dengan suplemen materi History of Mathematics (HoM) berorientasi pada motivasi, rasa ingin tahu dan prestasi belajar siswa yang valid, praktis, dan efektif berdasarkan kriteria Nieveen (1999, p.126).

Perangkat pembelajaran yang dikembangkan adalah Rencana Pelaksanaan Pembelajaran (RPP) dan modul. Rencana Pelaksanaan Pembelajaran (RPP) adalah suatu rencana kegiatan yang disusun secara sistematis yang berisikan prosedur atau langkah-langkah kegiatan guru dan siswa dalam pembelajaran (Trianto, 2013, p.214; Daryanto \& Dwicahyono, 2014, p.87; Kilpatrick \& Swafford, 2002, p.25). Dari hal tersebut peneliti akan melakukan penelitian pengembangan perangkat pembelajaran lingkaran SMP kelas VIII dengan suplemen materi History of Mathematics (HoM) dengan berorientasi pada motivasi, rasa ingin tahu, dan prestasi belajar siswa. Komponen dan prinsip pengembangan RPP dalam penelitian ini mengacu pada Permendikbud No. 65 Tahun 2013 tentang Standar Proses. modul adalah sarana pembelajaran dalam bentuk buku tertulis yang disusun secara sistematis, operasional, dan terarah untuk digunakan siswa secara mandiri, tanpa atau dengan bimbingan guru dalam proses pembelajaran berdasarkan kompetensi dasar atau indikator pencapaian kompetensi sehingga tercipta pembelajaran yang kondusif (Mulyasa, 2009, p.231; Nasution, 2006, p.205; Majid, 2011, p.176; Daryanto \& Dwicahyono, 2014, p.178).

\section{METODE}

\section{Jenis Penelitian}

Jenis penelitian ini merupakan penelitian pengembangan. Model pengembangan yang digunakan adalah model ADDIE. ADDIE merupakan konsep pengembangan produk. ADDIE merupakan singkatan dari Analysis, Design,
Development, Implementation, dan Evaluation (Branch, 2009, pp.17-18).

\section{Prosedur Pengembangan}

Tahap pertama adalah tahap analysis meliputi analisis kebutuhan, analisis siswa, dan analisis materi. Analisis kebutuhan bertujuan untuk mengetahui masalah-masalah yang dihadapi dalam pembelajaran matematika. Analisis siswa dilakukan untuk mengidentifikasi karakteristik siswa sesuai dengan jenjang pendidikannya menurut teori perkembangan peserta didik. Analisis materi digunakan untuk menentukan materi dalam penelitian berdasarkan kompetensi inti (KI) dan kompetensi dasar (KD) pada Standar Isi 2013. Tahap kedua adalah tahap design berupa penyusunan RPP dan Modul dengan suplemen materi HoM, serta instrumen evaluasi. Tahap ketiga adalah tahap development yaitu RPP dan Modul (draft 1) yang telah disusun divalidasi oleh ahli dan dilakukan revisi tahap 1. Selanjutnya tahap implementation yaitu produk pengembangan diujicobakan di sekolah dan dilakukan revisi tahap 2 apabila diperlukan. Yang terakhir adalah tahap evaluation yaitu dilakukan analisis kepraktisan dan keefektifan perangkat pembelajaran yang dikembangkan.

\section{Subjek Uji Coba, Waktu, dan Tempat Penelitian}

Subjek uji coba pada penelitian ini adalah siswa kelas VIII J di SMP Negeri 15 Yogyakarta yang terdiri atas 31 siswa. Penelitian ini dilakukan pada tanggal 27 Februari - 28 April 2015.

\section{Data, Teknik, dan Instrumen Pengumpulan Data}

Jenis data dalam penelitian ini terdiri atas data kuantitatif dan kualitatif. Data kuantitatif diperoleh dari hasil validasi ahli, penilaian guru, penilaian siswa, observasi keterlaksanaan pembelajaran, tes prestasi, dan angket kemandirian belajar matematika. Data kualitatif diperoleh dari komentar dan saran tentang produk pengembangan, serta hasil konversi data kuantitatif. Teknik pengumpulan data adalah tes dan non tes.

Instrumen pengumpulan data dalam penelitian ini terdiri atas (1) lembar validasi, (2) lembar penilaian guru, (3) lembar respon siswa, (4) lembar observasi, (5) tes prestasi belajar, (6) angket motivasi belajar siswa dan angket rasa ingin tahu siswa terhadap matematika. Data yang diperoleh digunakan untuk mengetahui 
validity (kevalidan), practicality (kepraktisan), effectiveness (keefektifan) dari produk yang dikembangkan. Hal ini sesuai dengan kriteria kualitas hasil produk yang dikemukakan oleh Nieveen.

\section{Teknik Analisis Data}

Teknik analisis data yang digunakan dalam penelitian ini adalah sebagai berikut. Data kualitatif berupa komentar dan saran dianalisis secara kualitatif, selanjutnya digunakan sebagai masukan untuk merevisi produk yang dikembangkan. Data kuantitatif berbentuk skala Likert dengan 5 kategori penilaian dikonversikan menjadi data kualitatif dengan acuan rumus yang diadaptasi dari Widoyoko (2009, p.238) pada Tabel 1.

Tabel 1. Kriteria Konversi Data

\begin{tabular}{cc}
\hline Interval Skor & Kategori \\
\hline$X>\bar{X}_{i}+1,8 S b i$ & Sangat baik \\
$\bar{X}_{i}+0,6 S b i<X \leq \bar{X}_{i}+1,8 \mathrm{Sbi}$ & Baik \\
$\bar{X}_{i}-0,6 S b i<X \leq \bar{X}_{i}+0,6 \mathrm{Sbi}$ & Cukup baik \\
$\bar{X}_{i}-1,8 S b i<X \leq \bar{X}_{i}-0,6 \mathrm{Sbi}$ & Kurang baik \\
$\mathrm{X} \leq \bar{X}_{i}-1,8 \mathrm{Sbi}$ & Sangat kurang \\
\hline
\end{tabular}

Keterangan :

$\bar{X}_{i}($ rerata ideal $)=\frac{1}{2}($ skor maksimum ideal + skor minimum ideal)

$S b i=\frac{1}{6}($ skor maksimum ideal - skor minimum ideal $)$ $X=$ Skor empiris

Teknik analisis data keefektifan ditinjau dari motivasi belajar dan rasa ingin tahu dengan menentukan persentase siswa yang mencapai kategori minimal tinggi, serta prestasi belajar dengan menentukan persentase ketuntasan siswa.

Perangkat pembelajaran dikatakan valid jika rata-rata penilaian ahli minimal dalam kategori "baik". Perangkat pembelajaran dikatakan praktis jika penilaian guru, respon siswa, serta persentase keterlaksanaan pembelajaran minimal dalam kategori "baik". Perangkat pembelajaran dikatakan efektif ditinjau dari motivasi dan rasa ingin tahu siswa jika hasil angket menyatakan bahwa skor empiris setelah penggunaan perangkat pembelajaran yang dikembangkan (angket akhir) lebih tinggi dibanding dengan skor empiris sebelum penggunaan perangkat pembelajaran (angket awal) dan minimal 80\% siswa di kelas tersebut telah mencapai kategori minimal tinggi. Sedangkan untuk prestasi belajar apabila minimal $80 \%$ siswa di kelas tersebut telah mencapai nilai kriteria ketuntasan minimal (KKM) yang ditetapkan oleh sekolah yaitu 75 .

\section{HASIL DAN PEMBAHASAN}

Hasil pengembangan produk berupa perangkat pembelajaran lingkaran dengan suplemen materi HoM menggunakan model ADDIE diuraikan sebagai berikut.

\section{Tahap analisis (analysis)}

Dari segi proses pembelajaran di kelas, metode, sumber belajar dan cara mengajar perlu mendapat pembaharuan. Pelajaran matematika yang diajarkan menggunakan buku ajar yang menekankan pada rumus dan pengerjaan soal. Dengan pendekatan seperti ini membuat pembelajaran matematika menjadi monoton dan tidak sesuai dengan standar proses yang diharapkan. Selain itu, sumber belajar yang digunakan kurang variatif. Ketika pembelajaran berlangsung, proses pembelajaran bertumpu pada buku paket yang cenderung didaktis. Dengan kondisi ini, motivasi, rasa ingin tahu dan prestasi belajar siswa kurang mendapat stimulus. Hasil dari pembelajaran yang monoton dan sumber belajar yang terbatas akan membuat matematika dianggap sebagai pelajaran yang tidak aplikatif dan jauh dari realitas kehidupan. Dari analisis kebutuhan tentang pemenuhan standar proses, kebutuhan akan bahan ajar dan yang perlu mendorong rasa ingin tahu dan motivasi siwa, maka perlu disusun suatu perangkat pembelajaran yang bisa mengatasi permasalahan tersebut.

Siswa SMP yang memasuki tahap remaja sudah mampu melakukan penalaran dan abstraksi. Kemampuan tersebut diperlukan dalam mempelajari geometri, maka suatu sistem pembelajaran yang menunjang karakteristik perkembangan siswa dan materi pembelajaran harus disusun. Suatu perangkat yang bisa menyajikan tidak hanya rumus dan latihan soal, namun juga bagaimana narasi tentang logika apa dibalik suatu konsep dan rumus matematika dibentuk perlu untuk disajikan.

\section{Tahap Perencanaan (Design)}

Hasil yang diperoleh dari tahap analisis baik analisis kebutuhan, analisis karakteristik siswa maupun analisis materi dijadikan dasar untuk menyusun perangkat pembelajaran. Penyusunan RPP sebagian besar dilakukan dengan mengacu pada aturan pengembangan RPP untuk kurikulum 2013 sebagaimana tertuang pada Peraturan Menteri Pendidikan dan Kebudayaan RI Nomor 65 Tahun 2013 tentang Standar Proses Pendidikan Dasar dan Menengah. Selain itu Peraturan Menteri Pendidikan dan Kebuda- 
yaan RI Nomor 81A Tahun 2013 tentang Implementasi Kurikulum juga turut menjadi pedoman dalam pengembangan RPP. Selanjutnya, pengembangan RPP juga disesuaikan dengan pendekatan pembelajaran dalam kurikulum 2013 yaitu pendekatan pembelajaran scientifik. Dalam penelitian ini dihasilkan 9 RPP dengan masingmasing RPP untuk satu kali pertemuan.

\section{Tahap Pengembangan (Development)}

Hasil dari tahap pengembangan berupa draft 2 RPP dan Modul dengan suplemen materi HoM setelah divalidasi oleh ahli dan dilakukan revisi sesuai dengan masukan dari validator. Validator dalam penelitian ini adalah (1) Drs. Sugiyono, M.Pd, (2) Drs. Edi Pajitno, M.Pd, dan (3) S. P Hartati, S.Pd. Hasil penilaian RPP dan Modul dari masing-masing validator disajikan dalam Tabel 2.

Tabel 2. Hasil Analisis Perangkat Pembelajaran

\begin{tabular}{cccccc}
\hline \multirow{2}{*}{ No } & Validator & \multicolumn{2}{c}{ RPP } & \multicolumn{2}{c}{ Modul } \\
\cline { 2 - 6 } & & $\begin{array}{c}\text { Total } \\
\text { skor }\end{array}$ & Kategori & $\begin{array}{c}\text { Total } \\
\text { skor }\end{array}$ & Kategori \\
\hline 1 & I & 165 & SB & 108 & SB \\
2 & II & 148 & B & 93 & B \\
3 & III & 177 & SB & 107 & SB \\
$\begin{array}{c}\text { Rata-rata skor } \\
\text { maksimal }\end{array}$ & \multicolumn{2}{c}{190} & \multicolumn{2}{c}{120} \\
$\begin{array}{c}\text { Total Skor } \\
\text { Rata-rata }\end{array}$ & 490 & & & 308 & SB \\
\hline
\end{tabular}

Ket: B (Baik), SB (Sangat Baik)

Berdasarkan hasil tersebut diketahui bahwa RPP dan Modul yang dikembangkan memenuhi kriteria valid dengan kategori sangat baik.

Tahap Implementasi (Implementation)

Hasil tahap implementasi adalah data hasil observasi keterlaksanaan pembelajaran, hasil penilaian guru, hasil respon siswa, hasil angket motivasi dan rasa ingin tahu, serta hasil tes prestasi belajar.

Tahap Evaluasi (Evaluation)

Hasil dari tahap evaluasi adalah hasil analisis kepraktisan dan keefektifan perangkat pembelajaran yang dikembangkan, serta produk akhir perangkat pembelajaran (RPP dan Modul) dengan suplemen materi HoM Kepraktisan berdasarkan hasil penilaian guru disajikan dalam Tabel 3.
Tabel 3. Hasil Analisis Kepraktisan berdasarkan Penilaian Guru

\begin{tabular}{cccc}
\hline No & Perangkat & Skor Empiris & Kategori \\
\hline 1 & RPP & 62 & Sangat Baik \\
2 & Modul & 75 & Sangat Baik \\
& Skor Maksimal & 150 \\
\multicolumn{2}{l}{ Total } & 137 & Sangat Baik \\
\hline
\end{tabular}

Berdasarkan Tabel 3, dapat dilihat bahwa perangkat pembelajaran yang dikembangkan masuk dalam kategori sangat baik. Hasil observasi keterlaksanaan pembelajaran yang dilakukan oleh dua observer disajikan dalam Tabel 4.

Tabel 4. Hasil Observasi Keterlaksanaan Pembelajaran

\begin{tabular}{cccc}
\hline \multirow{2}{*}{ Pertemuan Ke } & \multicolumn{3}{c}{ Keterlaksanaan KBM } \\
\cline { 2 - 4 } & Skor & $\%$ & Kategori \\
\hline 1 & 36 & 90 & SB \\
2 & 40 & 100 & SB \\
3 & 28 & 70 & B \\
4 & 40 & 100 & SB \\
5 & 28 & 70 & B \\
6 & 40 & 100 & SB \\
7 & 38 & 95 & SB \\
8 & 40 & 100 & SB \\
9 & 38 & 95 & SB \\
Total & 328 & 91,11 & SB \\
\hline
\end{tabular}

Ket: B (Baik), SB (Sangat Baik)

Berdasarkan Tabel 4 diketahui bahwa rata-rata persentase keterlaksanaan pembelajaran pada pada kategori sangat baik.

Rata-rata penilain siswa terhadap perangkat pembelajaran adalah 49,71 dari skor maksimal 60. Berdasarkan hasil penilaian siswa, dapat dilihat bahwa perangkat pembelajaran yang dikembangkan masuk dalam kategori baik. Hasil penilaian siswa tiap aspek dapat dilihat pada Tabel 5.

Tabel 5. Hasil Respon Siswa terhadap Modul Per Aspek

\begin{tabular}{cccc}
\hline No & Aspek Penilaain & Skor Empiris & Kategori \\
\hline 1 & Kemudahan & 37,35 & Baik \\
2 & Kemenarikan & 8,39 & Baik \\
3 & Kemanfaatan & 3.97 & Baik \\
& Skor Maksimal & & $\mathbf{6 0}$ \\
& Total & $\mathbf{4 9 , 7 1}$ & Baik \\
\hline
\end{tabular}

Berdasarkan hasil analisis penilaian guru, data observasi keterlaksanaan pembelajaran, dan respon siswa, dapat disimpulkan bahwa perangkat pembelajaran yang dikembangkan memenuhi kriteria praktis untuk digunakan.

Keefektifan perangkat pembelajaran berdasarkan hasil angket motivasi belajar disajikan dalam Tabel 6. 
Tabel 6. Hasil Analisis Angket Motivasi Belajar

\begin{tabular}{|c|c|c|c|c|}
\hline \multirow[b]{2}{*}{ Kategori } & \multicolumn{2}{|c|}{ Angket Awal } & \multicolumn{2}{|c|}{ Angket Akhir } \\
\hline & $\begin{array}{c}\text { Banyaknya } \\
\text { siswa }\end{array}$ & $(\%)$ & $\begin{array}{c}\text { Banyaknya } \\
\text { siswa }\end{array}$ & $(\%)$ \\
\hline $\begin{array}{l}\text { Sangat } \\
\text { Tinggi }\end{array}$ & 0 & 0 & 3 & 9,68 \\
\hline Tinggi & 15 & 48,39 & 24 & 77,42 \\
\hline Sedang & 16 & 51,61 & 4 & 12,90 \\
\hline Rendah & 0 & 0 & 0 & 0 \\
\hline $\begin{array}{l}\text { Sangat } \\
\text { Rendah }\end{array}$ & 0 & 0 & 0 & 0 \\
\hline Jumlah & 31 & 100 & 31 & 100 \\
\hline \multicolumn{4}{|c|}{ Rata-rata Skor Maksimal } & 120 \\
\hline $\begin{array}{c}\text { Rata-rata } \\
\text { Skor } \\
\text { Empiris } \\
\text { Kategori }\end{array}$ & \multicolumn{2}{|c|}{80,77} & \multicolumn{2}{|c|}{87,48} \\
\hline
\end{tabular}

Berdasarkan Tabel 6, perangkat yang dikembangkan efektif karena rata-rata skor angket akhir lebih besar dari rata-rata skor angket awal dan lebih dari $80 \%$ siswa mencapai kategori minimal tinggi pada angket akhir.

Keefektifan perangkat pembelajaran berdasarkan hasil angket rasa ingin tahu terhadap matematika disajikan dalam Tabel 7.

Tabel 7. Hasil Analisis Angket Rasa Ingin Tahu

\begin{tabular}{|c|c|c|c|c|}
\hline \multirow[b]{2}{*}{ Kategori } & \multicolumn{2}{|c|}{ Angket Awal } & \multicolumn{2}{|c|}{ Angket Akhir } \\
\hline & $\begin{array}{c}\text { Banyaknya } \\
\text { siswa }\end{array}$ & $(\%)$ & $\begin{array}{c}\text { Banyaknya } \\
\text { siswa }\end{array}$ & $(\%)$ \\
\hline $\begin{array}{l}\text { Sangat } \\
\text { Tinggi }\end{array}$ & 0 & 0 & 3 & 9,68 \\
\hline Tinggi & 12 & 38,71 & 24 & 77,42 \\
\hline Sedang & 19 & 61,29 & 4 & 12,90 \\
\hline Rendah & 0 & 0 & 0 & 0 \\
\hline $\begin{array}{l}\text { Sangat } \\
\text { Rendah }\end{array}$ & 0 & 0 & 0 & 0 \\
\hline Jumlah & 31 & 100 & 31 & 100 \\
\hline \multicolumn{4}{|c|}{ Rata-rata Skor Maksimal } & 120 \\
\hline $\begin{array}{c}\text { Rata-rata } \\
\text { Skor } \\
\text { Empiris } \\
\text { Kategori }\end{array}$ & \multicolumn{2}{|c|}{79,58} & \multicolumn{2}{|c|}{88,00} \\
\hline
\end{tabular}

Berdasarkan Tabel 7, perangkat yang dikembangkan efektif karena rata-rata skor angket akhir lebih besar dari rata-rata skor angket awal dan lebih dari $80 \%$ siswa mencapai kategori minimal tinggi pada angket akhir.

Keefektifan perangkat pembelajaran berdasarkan hasil tes prestasi belajar disajikan dalam Tabel 8.
Tabel 8. Hasil Analisis Tes Prestasi Belajar

\begin{tabular}{cc|}
\hline Banyaknya siswa & Tuntas \\
\hline 31 & 26 \\
Skor Maksimal & 100 \\
KKM & 75 \\
Rata-rata & $\mathbf{8 2}$ \\
Persentase (\%) & $\mathbf{8 3 , 8 7}$ \\
\hline
\end{tabular}

Berdasarkan Tabel 8 , perangkat yang dikembangkan efektif karena persentase ketuntasan siswa yang mencapai KKM lebih dari $80 \%$.

Kevalidan Produk

Berdasarkan penilaian para ahli, produk akhir perangkat pembelajaran dengan suplemen materi History of Mathematics (HoM) yang terdiri dari rencana pelaksanaan pembelajaran (RPP) dan modul masing-masing telah memenuhi kriteria valid dengan kategori sangat baik. Perangkat pembelajaran dengan suplemen materi History of Mathematics (HoM) juga telah direvisi berdasarkan masukan atau saran dari ahli sehingga layak untuk digunakan. Perangkat pembelajaran valid karena dalam pengembangannya, perangkat pembelajaran telah didasarkan pada teori-teori yang relevan.

\section{Kepraktisan Produk}

Berdasarkan hasil uji lapangan diketahui bahwa RPP dan Modul yang dihasilkan telah mencapai kategori praktis. Hal ini dapat dilihat dari hasil penilaian guru, respon siswa, dan observasi keterlaksanaan pembelajaran. Berdasarkan hasil penilaian guru terhadap RPP dan Modul dapat disimpulkan bahwa RPP dan Modul telah praktis dengan kategori sangat baik.

Berdasarkan hasil respon siswa dapat disimpulkan bahwa perangkat pembelajaran telah praktis dengan kategori baik. Berdasarkan hasil observasi keterlaksanaan pembelajaran dapat disimpulkan bahwa RPP dan Modul dinyatakan praktis dengan keterlaksanaan pembelajaran mencapai $91,11 \%$.

\section{Keefektifan Produk}

Berdasarkan uji lapangan yang telah dilaksanakan menunjukkan bahwa perangkat pembelajaran dengan suplemen materi History of Mathematics (HoM) yang dihasilkan telah memenuhi kriteria efektif. Hal ini dapat dilihat dari tes prestasi belajar siswa yang hasilnya menunjukkan bahwa lebih dari $80 \%$ siswa telah mencapai Kriteria Ketuntasan Minimal (KKM). Dengan persentase ketuntasan yang lebih dari 
$80 \%$ berarti tujuan pembelajaran telah tercapai dan produk yang dikembangkan secara umum dinilai efektif sehingga layak untuk digunakan. Selain dilihat dari hasil tes prestasi belajar siswa, keefektifan perangkat pembelajaran dengan suplemen materi History of Mathematics (HoM) juga dilihat dari motivasi dan rasa ingin tahu siswa yang hasilnya menunjukkan bahwa ratarata skor empiris angket akhir lebih tinggi dari rata-rata skor empiris angket awal serta lebih dari $80 \%$ siswa memiliki tingkat motivasi belajar dan rasa ingin tahu terhadap matematika yang minimal tinggi. Dengan perolehan rata-rata skor empiris angket akhir lebih tinggi dari ratarata skor empiris angket awal serta persentase tingkat motivasi belajar dan rasa ingin tahu dengan kategori minimal tinggi lebih dari $80 \%$ berarti tujuan pembelajaran telah tercapai dan produk yang dikembangkan secara umum dinilai efektif sehingga layak untuk digunakan.

Efektifnya perangkat pembelajaran dengan suplemen materi History of Mathematics (HoM) karena pembelajaran menggunakan modul dengan suplemen materi History of Mathematics (HoM) mengupayakan agar siswa belajar matematika secara bermakna melalui keterlibatan siswa secara aktif dalam pembelajaran sehingga membuat siswa dapat lebih memahami materi yang dipelajari.

Hasil penelitian ini sesuai dengan pendapat dari Goktepe \& Ozdemir (2013, p.126) yang menyatakan bahwa pengetahuan sejarah matematika bisa membantu siswa mengembangkan sikap positif mereka terhadap matematika. Dengan adanya cuplikan sejarah, anekdot dan biografi tokoh, siswa dapat melihat sisi lain dari matematika yang lebih menyenangkan dan humanis. Dengan sikap positif inilah siswa terdorong dan termotivasi untuk lebih giat dalam belajar matematika. Tanpa hal tersebut, siswa akan selalu merasa matematika adalah momok dan hal yang ditakuti. Dengan narasi sejarah dalam perkembangan matematika, siswa dapat melihat bahwa ide-ide tentang konsep matematika berasal dari permasalahan pada zamannya. Ini menunjukkan bahwa matematika lahir untuk menyelesaikan persoalan yang ada dalam masyarakat di kala itu.

Berdasarkan pandangan bahwa matematika lahir dari suatu konteks tertentu, siswa akan sadar bahwa matematika sangat berkaitan erat dengan kehidupan mereka. Seperti yang dinyatakan oleh Goktepe \& Ozdemir (2013, p.126) "they can see that mathematic is a science that people created in accordance with the needs of people." Dengan anggapan ini, siswa akan terpacu untuk belajar materi matematika yang diajarkan. Dengan inilah perangkat pembelajaran dengan suplemen HoM bisa efektif dalam menumbuhkan motivasi dan rasa ingin tahu serta prestasi belajar siswa.

\section{SIMPULAN DAN SARAN}

\section{Simpulan}

Berdasarkan hasil penelitian dan pengembangan diperoleh simpulan bahwa perangkat pembelajaran lingkaran SMP kelas VIII dengan suplemen materi History of Mathematics (HoM) berorientasi pada motivasi, rasa ingin tahu, dan prestasi belajar siswa yang terdiri atas RPP dan modul masing-masing memenuhi kriteria valid, praktis, dan efektif.

\section{Saran}

Perangkat pembelajaran lingkaran SMP kelas VIII dengan suplemen materi History of Mathematics (HoM) berorientasi pada motivasi, rasa ingin tahu, dan prestasi belajar siswa yang terdiri atas RPP dan modul telah teruji kelayakannya, yaitu memenuhi kriteria valid, praktis, dan efektif sehingga disarankan kepada guru matematika untuk menggunakan perangkat ini untuk menumbuh kembangkan motivasi, rasa ingin tahu, dan prestasi belajar siswa. Guru hendaknya berusaha mengatasi berbagai kendala ketika siswa menggunakan modul, sehingga proses belajar akan lebih baik. Walaupun modul memang dirancang agar bisa digunakan secara mandiri oleh siswa, tidak menutup kemungkinan siswa mendapat hambatan dalam penggunaan modul.

\section{DAFTAR PUSTAKA}

Arends, D., \& Kilcher, A. (2010). Teaching for student learning: Becoming an accomplished teacher. New York: Routledge.

Azwar, S. (2000). Penyusunan skala psikologi. Yogyakarta: Pustaka Pelajar Offset.

Badan Standar Nasional Pendidikan (BSNP). (2013). Laporan hasil ujian nasional SMP/MTS tahun pelajaran 2012/2013. Jakarta: BSNP.

Badan Standar Nasional Pendidikan (BSNP). (2013). Laporan hasil ujian nasional SMP/MTS tahun pelajaran 2013/2014. Jakarta: BSNP. 
Branch, R. M. (2009). Instructional design: the ADDIE approach: proceedings of the second sussex conference, 1977 (Vol. 722). New York: Springer Science \& Business Media.

Cohen, R. J., Swerdlik, M. E., \& Phillips, S. M. (2005). Psychological testing and assessment: an introduction to tests and measurement. New York: McGraw-Hill.

Dai, D. Y., \& Sternberg, R. J. (Eds.). (2004). Motivation, emotion, and cognition: Integrative perspectives on intellectual functioning and development. New Jersey: Routledge.

Daryanto., \& Dwicahyono, A. (2014). pengembangan perangkat pembelajaran. (silabus, RPP, PHB, bahan ajar). Yogyakarta: Gava Media.

Djamarah, S. B. (2002). Psikologi pendidikan. Jakarta: Rineka Cipta.

Engel, S. (2015). The hungry mind: the origins of curiosity in childhood. Cambridge, Massachusetts: Harvard University Press.

Evans, L. (1999). Managing to motivate. London: Cassell.

Florian, L., Rouse, M., \& Hawkins, K. B. (2007). Achievement and inclusion in schools. New York: Routledge.

Goktepe, S., \& Ozdemir, A. S. (2013). An example of using history of mathematics in classes. Dalam European Journal of Science and Mathematics Education Vol, 1(3), 125.

Gonzales, P., et al. (2009). Highlights from TIMSS 2007: mathematics and science achievement of U.S. fourth- and eighthgrade students in an international context (NCES 2009-001 revised). Washington, DC: U.S. Government Printing Office.

Gronlund, N. E. (1982). Constructing achievement tests. Englewoods Cliffs: Prentice Hall.

Hook, P., \& Vass, A. (2011). Behaviour management pocketbook. Hamsphire: Teacher's Pocketbooks.

Ho, W. K. (2008). Using history of mathematics in the teaching and learning of mathematics in Singapore. Dalam $1 s t$
Raffles International Conference on Education, Singapore.

John R Durbin (2012). e-Study Guide for: modern algebra: an introduction cram101 textbook reviews. Content Technology Publication.

Jones, J. B., \& Flint, L. J. (Eds.). (2013). The creative imperative: school librarians and teachers cultivating curiosity together. Santa Barbara, California: Libraries Unlimited ABC-CLIO.

Kemdikbud. (2013a). Peraturan Menteri Pendidikan dan Kebudayaan RI Nomor 66, Tahun 2013, tentang Standar Proses Penilaian.

Kemdikbud. (2013b). Peraturan Menteri Pendidikan dan Kebudayaan RI Nomor 65, Tahun 2013, tentang Standar Proses Pendidikan Dasar dan Menengah.

Kilpatrick, J \& Swafford, J. (Eds.). (2002). Helping children learn mathematics. Washington DC: National Academies Press.

Lim, S. Y., \& Chapman, E. (2010). Using history to enhance student learning and attitudes in Singapore mathematics classrooms. Dalam Education, Research and Perspectives, 37(2), 110.

Loewenstein, G. (1994). The psychology of curiosity: A review and reinterpretation. Dalam Psychological bulletin, 116(1), 75 .

Majid, A. (2007). Perencanaan pembelajaran meningkatkan standar kompetensi guru. Bandung: PT. Remaja Rosdakarya.

Mulyasa, E. (2006). Kurikulum yang disempurnakan. Bandung: Remaja Rosda Karya.

Nasution, S. (2000). Berbagai pendekatan dalam proses belajar dan mengajar. Jakarta: PT. Bina Aksara.

Nayazik, A. (2012). Pembelajaran matematika dengan mengintegrasikan hom (History Of Mathematics) untuk meningkatkan motivasi belajar. Prosiding seminar nasional matematika dan pendidikan matematika 2012, UNY, 1-8.

Nieveen, N. (1999). Prototyping to reach product quality. Dalam Aker, J.(eds). 


\section{Pythagoras, 10 (2), Desember 2015 - 221}

Tri Hidayati, Djamilah Bondan Widjajanti

(1999). Design approaches and tools in education and training (pp. 125-135). Dordrecht: Springer Netherlands.

Organisation for Economic Co-operation and Development (OECD). (2014). PISA 2012 results in focus what 15-year-olds know and what they can do with what they know. Paris: OECD.

Santoso, F. G. I. (2011). Mengasah kemampuan berpikir kreatif dan rasa ingin tahu melalui pembelajaran matematika dengan berbasis masalah (suatu kajian teoritis). Dalam Prosiding Seminar Nasional Matematika dan Pendidikan Matematika FMIPA UNY.

Santrock, J. W. (2007). Perkembangan anak. (alih bahasa: Mila Rachmawati, Anna Kuswanti). Jakarta: Erlangga.

Sardjoko, T. (2011). Efektivitas model pembelajaran kooperatif tipe numbered heads together dan group investigation pada prestasi belajar matematika ditinjau dari motivasi berprestasi siswa SMA di Kabupaten Ngawi. Disertasi Doktor. Tidak diterbitkan, Universitas Sebelas Maret, Solo.
Sulistyowati, E. (2012). Implementasi kurikulum pendidikan karakter. Yogyakarta: Citra Aji Parama.

Swetz, F. J. (1994). Learning activities from the history of mathematics. Portland, ME: Walch Publishing.

Trianto. (2009). Mendesain model pembelajaran inovatif-progresif: konsep, landasan, dan implementasinya pada kurikulum tingkat satuan pendidikan (KTSP). Jakarta: Kencana.

Wahyuni, A., \& Abadi, A. (2014). Perbandingan keefektifan pembelajaran cooperative learning type STAD dan type TPS pada pembelajaran bangun ruang siswa SMP. Jurnal Riset Pendidikan Matematika, $\quad l(2), \quad$ 164-175. doi:http://dx.doi.org/10.21831/jrpm.v1i2. 2673

Widoyoko, E. P. (2009). Evaluasi program pembelajaran. panduan praktis bagi pendidik dan calon pendidik, Yogyakarta: Pustaka Pelajar.

Winkel, W. S. (1996). Psikologi pembelajaran. Jakarta: Gramedia.

Zuss, M. (2011). The practice of theoretical curiosity (Vol. 20). New York: Springer Science \& Business Media. 